\title{
Worldview and Health in I. Kant's Ethics Theology
}

\author{
Nur Kirabaev ${ }^{1}$ Sergei Nizhnikov ${ }^{1, a, *}$
}

\author{
${ }^{1}$ Department History of Philosophy, Peoples' Friendship University of Russia (RUDN University), Moscow, Russia \\ ${ }^{\mathrm{a}}$ E-mail: kirabaev_ns@rudn.ru \\ *Corresponding author. E-mail: nizhnikov_sa@rudn.ru
}

\begin{abstract}
In the article, based on the conception of Diatetik, developed by I. Kant, the authors consider the interrelation of physical, mental, and spiritual (moral) health. The authors define philosophy as the worldview science directed on achieving the complex health of a person, thus opening transcendental bases of moral philosophy. At the same time, Kant's ethics theology does not recognize former spiritualism (metaphysical, transcendental one). The moral theology has only immanent application, and all ideas of reason do not get speculative but imperative character. According to Kant, morality, instead of mind, is what makes someone an authentic individual. The philosopher speaks about the necessity of "ethical gymnastics." Physical health is only a part of wellbeing for the completeness of which it is necessary to add something purely moral. Kant believed, that the moral culture is needed for the physical integrity of human nature, that the moral philosophy is also a "universal medicine." He named culture of virtue moral ascetics and Diatetik, whose purpose is to contain oneself in morally healthy conditions.
\end{abstract}

Keywords: Diätetik, spiritual and moral health, culture of virtue, moral asceticism, ethics theology, transcendental philosophy

\section{INTRODUCTION}

First, philosophy cares about spiritual health, from which a person may build the right guidance for fulfilling mental and bodily lives. According to Epicurus, useless are the words of a philosopher, that do not cure human suffering, and it is philosophy necessary for the health of the soul [1]. An individual is a microcosm, uniting in this sense three levels of being: material (biological, bodily), mental, and spiritual. Therefore, we may consider the concept of health from these three points of view. However, in a harmonious personality, they should be integrated, to which contemporary reality often actively opposes. Superstitions, so common in contemporary societies, also hinder such forming-up. Philosophy is incompatible with superstitions; moreover, one of its primary functions is to cleanse the mass and individual consciousness from the incipient inadequacy of mental and physiological diseases, following worldview disorientation.

This function proved itself correctly in the works of Immanuel Kant. His words, "Sapere aude! - have the courage to use your own mind" [2] may be the motto of philosophical Weltanschauung. It may seem to ordinary

*Fund: The reported study was funded by RFBR and MOST according to the research project № 20-511-S52002 "Philosophy of Being Human as the Core of Interdisciplinary Research". people that they think for themselves, but in fact, their consciousness is filled with tropes, stereotypes imposed by mass culture. Those who can think independently are already philosophizing. Independent thinking, philosophy, is necessary not only for learning the truth of being but also for finding health, above all, mental and spiritual. By the latter, I. Kant understands morality, which determines the behavior of an individual, personal attitude towards oneself and the others, and the world as a whole.

\section{HEALTH IN HISTORICAL AND CULTURAL CONTEXT}

Considering the concept of health in the historical context, a researcher may state that the ancient worldview is characterized by the principle of kalokagathos (Greek kalos - "beautiful" and agathos "good"), at the basis of which is the fusion of the perfection of body and spirit, with the latter unthinkable without the former [3]. Medieval culture places in the center the concept of spiritual goodness based on the attitude to the transcendent origin through faith. Thus, the medieval Christian Weltanschauung based on entirely different principles, its touchstone is theocentricism, replacing the ancient cosmocentrism. According to this new principle, a scholar should view the concept of health and the ways of achieving it, the relationship between soul and body, in a completely 
new way. Reflection on this embodiment is the metaphysics of faith [4].

Yet, Christian radicalism concerning the exclusively spiritual concept of health, "transcendent egoism" [5], sometimes led to the oblivion of the human body's needs, when emerged the ideas that only the soul should be cured, for it begets all the diseases, i.e., sins. In a weak body, the spirit grows, and physical health is not only unnecessary but is often harmful since it leads the thoughts away from the idea of salvation. Hence, the nihilism to the body and everything sensual. Vasily Rozanov and Nikolai Berdyaev felt this extremely acute in the Russian culture, and Friedrich Nietzsche and Martin Heidegger - in the Western one, calling culture of transcendent origin a nihilism, i.e., proving it in leveling the values of earthly existence and bodily health of an individual.

Nietzschean Übermensch must have a healthy physique, hence Nietzsche's cult attitude towards physicality. Thought, faith, and knowledge drain and kill the body. Spirit, in general, is an extension of the body. The body represents the human Self. The essence of the body is the life force, the energy, that Nietzsche calls It. "There is more intelligence in your body than in your higher wisdom," - writes the German philosopher. He continues: "I am body through and through, nothing more; and the soul is just a word for something on the body"; "Blood is spirit." He thus believes that the metaphysical attitude of a Westerner, originating in the Christian Weltanschauung, leads to nihilism, to the oblivion of the interests of the real life, to the "fading of living instinct." M. Heidegger criticizes even more heavily, ontologically, traditional "lying beyond the bounds" metaphysics, although the philosopher recognizes that God can only take the place of God. At the same time, for undistorted Christianity, health is a gift from God, so an individual should not neglect their health, including the physical one.

Kant, also belonging to the New European culture, reflects and asserts its values. He pays special attention to history, culture, morality, politics, and upbringing after completing his major work Critique of Pure Reason, in which he designs the transcendental foundations of the philosophy of morality, raising, and education. Let us discover these philosophical premises.

In traditional metaphysics, ethics bases on axiomatic, transcendent foundations that combine in themselves ontological and axiological aspects (the Absolute is necessarily good). This philosophy is a "regulatory theology," i.e., it's oriented not only at the achievement of knowledge and truth but also at its virtues; the latter makes the final verdict on the fitness or unfitness of this or that philosophical system. Transcendental philosophy seeks, first of all, the truth only, which may beget the authentic truth. The ideal of philosophical upbringing stays here as well. Still, it breaks free of theology and teleology, their transcendent aims, sometimes "denigrating" people with their weight and significance of unconditional demands. The criterion of virtue rests on the a priori foundations of practical reason. Theology is allowed, but it takes on a postulated rather than metaphysical characteristics, i.e., it turns into ethics.

\section{MORALITY AS TOUCHSTONE OF HEALTH}

Immanuel Kant believed that a person belongs to two worlds at once: to the speculative (noumenal) with spiritual and moral being, and the empirical (phenomenal, sensual) with physical being [6]. A human being is biological by nature, social and spiritual - by essence. The biological formation is valuable just as the formation of the material basis of one's existence. A human is defined by the features, distinguishing from the animal kingdom, and these being the spiritual sphere of society and soul

Kant understood that the conclusions in the first Critique were destructive not only for metaphysics but also for the morality based on it. After all, humanity has been living based on those ideas, which he calls transcendental illusion, and which are deprived of ontological status (since they aren't based on a priori synthetic judgments), since the dawn of time. If someone eliminates these ideas (of God, virtue, immortality, etc.) by erasing their objectivity (ontological, a priori status), then an individual as a reasonable moral being will be eliminated as a carrier of these ideas. Therefore, Kant faces yet another task after once again defeating traditionally understood metaphysics. To substantiate morality in such a way (for its former foundation is destroyed under the blows of Critique) that this substantiation doesn't contradict the provisions, formulated in Critique (deontologisation of metaphysical ideas of reason).

For carrying out this task, Kant sets the following question: if ideas of reason and the three principal positions (Go, immortality, and freedom) are utterly useless for our knowledge in theoretical terms (according to Kant), then will they be applicable practically? To pose a question like that, Kant divides reason into theoretical and practical ones: will the ideas of reason be productive if not in theoretical then in the practical sphere, to which he counts morality. Kant concludes that moral laws belong to the area of the practical application of pure reason.

Following the path of rehabilitating the spiritual sphere, Kant, on the other ways, comes to the statement of what he denies in the first Critique. It turns out that the principles of pure reason have objective reality in their practical, moral implementation. Kant affirms the concept of the moral world, i.e., the one that should be per the laws of morality. This world is considered to be intelligible only, and it is the idea that has an impact on 
the sensual world. Therefore, the view of the moral world has an objective and practical reality.

Kant builds, so to say, using a phrase by himself [7], moral or transcendental theology (ethics theology) based on transcendental principles since the speculative (metaphysical, transcendent) theology he disproved in his first Critique. Moral theology, following Kant, has just an immanent application, i.e., it is intended for execution in this world without a direct connection of behavior to the idea of the supreme being (which would give reason a transcendent application). The ethics theology must be built upon the objective belief of the mind and not on the subjective belief of an individual, which, according to Kant, is random.

The doctrine of the existence of God, for Kantian ethics, is only a doctrinal belief, i.e., something that isn't based on knowledge but is only accepted by the majority. The existence of God and the afterlife is not logically but morally reliable, basing solely on the a priori premises of the moral order of an individual. With this moral theology, Kant seeks to make up for the losses resulted from the destructive power of the first Critique. The philosopher restores the notion of a single, omnipotent, and intelligent being, considering it great merit of his second Critique. However, the restoration is of a completely different quality, where all ideas of reason acquire not a speculative-ontological but rather an imperative-regulatory feature.

All of this has led Kant to a well-known complete reassessment of the relationship between morality and religion: "... morality doesn't need religion; due to pure practical reason, it overcomes itself". Nevertheless, "morality inevitably leads to religion". [8] Everyone, so Kant, must set the highest possible good in virtue as the ultimate personal goal. Moral perfection also leads to the physical one; at the very least, it helps to maintain health and overcome illnesses.

\section{KANT'S DIÄTETIK}

According to Kant, "Philosophy is the health of the mind (status salubritatis); this is its effect," it "should therapeutically act as a cure (material medica)" [9]. In his youth, the German philosopher was frail. The doctors foretold him short and unproductive life. Yet, the philosopher developed a set of rules, Diätetik ${ }^{1}$, daily routine, which he followed strictly throughout his life. He considered Diätetik to be the "ability to prevent illnesses, unlike therapy, which seeks to cure them." Therapy acts negatively as a way of disease prevention. He described Diätetik's provisions in his work On the Power of the Spirit Alone to Overcome Painful Feelings: Diätetik "assumes ability that only

Usual English translation Kant's Diätetik as "dietetics" is wrong, because it has nothing with the diet. Kant's Diätetik has worldview and moral sense. philosophy or its spirit may provide" [10]. In his last published work Anthropology from a Pragmatic Point of View (1798), Kant states in his seventy-fifth year of life: "... work is the best way to enjoy life". The philosopher's biographers note that Kant enjoyed repeating the saying, "command your nature, or it will command you." He proceeded from the principle "work is the best way to enjoy life - the more you do, the more you live" [11].

Kant stresses, referring to Stoicism, that philosophy can be useful to humankind not only as a science of virtue but also as a healing science. The latter is possible when a person reasonably determines his or her way of life and takes control of the feelings. If reason resorts to external services, to the means of physiological influences (medication, etc.), then we're talking about mechanical, empirical, not philosophical treatment. Kant also calls scientists to "observe the diet of thinking" [12], giving themselves rest.

In his letter to Hufeland (1797), Kant writes of his intention to outline and send his addressee a plan of Diätetik to demonstrate "the power of spirit over painful physical sensations." As a cure, Kant assumes only the measures of psychological influence, which at that time were not yet applied in medical practice. $\mathrm{He}$ writes about himself, that, despite his 74th birthday, the once developed remedies allow him to avoid many diseases safely. Unfortunately, the philosopher had so many things to attend to, thus preventing him from revealing his secrets of high efficiency. In his letter to K. C. Schoen (1802), Kant admits that his powers are melting by the day yet notes that he has never really been ill or has feared any severe illness. He considered moral culture to be necessary for the physical completion of human nature, that "moral, practical philosophy is also a universal medicine that doesn't cure everything but must be present in every treatment" [13]. Physical health is only a part of wellbeing for the fullness of which one must add something else, purely moral. Kant relies on moral advances in an individual that are supersensitive, yet not supernatural. The philosopher denies any influence of mystical experiences, calling them suffocative (heartbreaking) and sentimental. In the mystical sense, he criticizes the unnaturalness of faith if the subjective conditions of its emergence replace the goal - a virtuous life [14].

\section{Conclusion}

According to Kant, "... the plan of upbringing must be designed from a cosmopolitan perspective". "There is the principle of the art of upbringing, which people, responsible for designing education plans, should always have at hand: children should be brought up not for the present but the future, possibly for the best possible one, state of the humanity, i.e., for the idea of mankind and following its general purpose" [15]. 
Humanist pedagogy should be the most crucial component in the process of nurturing, education, and upbringing should contribute to the establishment of friendship among countries and peoples.

Kant called the culture of virtue moral ascetics and Diätetik, the purpose of which to keep oneself in a morally healthy state [16]. Morality as the basis of faith (religion) ends where "the human race ends," it "is initially common for everyone" because it has a priori status. Critique of Pure Reason "defined an individual's exceptionally active existence" in the world, according to which "a person is from the beginning the creator of own notions and conceptions and must be the sole source of own actions." According to Kant, the moral law "pulls us completely out of [shackles] of nature and elevates us above it." It provides a "quality that is unique to humans and that distinguishes them from the rest of nature - morality, through which we are independent and free beings...".

Further on: "Exactly this morality and not reason is that makes up a human being" [17]. That is why Kant speaks about the need for ethical gymnastics, without which there will be no full-fledged health. Yet the spiritual (metaphysical) traditions, such as Christianity, yoga, Buddhism, etc., teach the same. Moral health morality - creates internal conditions for bodily health. Vice versa, the destruction of moral order inevitably leads to mental deformations of consciousness and physical illnesses.

\section{References}

[1] Anthology of World Philosophy. In 5 vol. Vol. 1, Part 1. M.: Publisher "Mysl", 1969, p. 354.

[2] I. Kant, "An Answer to the Question: What Is Enlightenment?" in Collected Works. In 8 vols. Vol. 8. M.: Publisher "Choro", 1994, p. 29.

[3] A.V. Semushkin, "Ancient Kalokagathos as a Prerequisite of Educational Paradigm," in Philosophy of Education in the Multicultural Society of the 21st Century. Collection of Articles. Moscow: RUDN University Publishing House, 2010, p. 73.

[4] S.A. Nizhnikov, Metaphysics of Faith in Russian Philosophy. 2nd Edition. M.: Publisher INFRA-M, 2017, p. 301.

[5] N. Berdyaev, "Salvation and Creativity" in Philosophy of Freedom; The Meaning of Creativity. M.: Publisher "Pravda," 1989 , p. 354.

[6] I. Kant, The Contest of Faculties. Kaliningrad: Publisher KGU, 2002, p. 174.

[7] I. Kant, "Critique of Pure Reason" in Collected Works. In 8 vols. Vol. 3. M., 1994. p. 594.

[8] I. Kant, "Religion within the Limits of Reason Alone" in Collected Works. In 8 vols. Vol. 6. M., 1994, p. 8.

[9] I. Kant, The Contest of Faculties, p. 274.

[10] Ibid., p. 224-269, 226.

[11] A. Gulyga, "Revolution of Spirit: (Life and Works of Immanuel Kant)" in Kant I. Collected Works. In 8 vols. Vol. 1. M., 1994, p. 7 .
[12] I. Kant, The Contest of Faculties, pp. 234, 252.

[13] Ibid., p. 226.

[14] Ibid., p. 136, 146

[15] I. Kant, "On Pedagogy" in Collected Works. In 8 vols. Vol. 8. M., 1994, p. 406.

[16] I. Kant, "Foundations of the Metaphysics of Morals" in Collected Works. In 8 vols. Vol. 6. M., 1994, p. 533.

[17] I. Kant, The Contest of Faculties, pp. 173-174, 180. 